\title{
The entrepreneurial finance markets of the future: a comparison of crowdfunding and initial coin offerings
}

\author{
Joern H. Block • Alexander Groh • Lars Hornuf • Tom \\ Vanacker • Silvio Vismara
}

Accepted: 19 January 2020 / Published online: 7 April 2020

(C) The Author(s) 2020

\begin{abstract}
Entrepreneurial finance markets are in a dynamic state. New market niches and players have developed and continue to emerge. The rules of the game and the methods for receiving financial backing have changed in many ways. This editorial and the special issue of Small Business Economics focus on crowdfunding $(\mathrm{CF})$ and initial coin offerings (ICOs), which are two distinct but important entrepreneurial finance market segments of the future. Although the two market segments initially appear to be similar, we identify differences between them. Our comparison focuses on the stakeholders, microstructures, regulatory environments, and
\end{abstract}

J. H. Block $(\bowtie)$

Department of Management, Fachbereich IV, Universität Trier, Universitätsring 15a, 54296 Trier, Germany

e-mail: block@uni-trier.de

J. H. Block

Universität Witten/Herdecke, Witten, Germany

J. H. Block

Erasmus University Rotterdam, Rotterdam, Netherlands

A. Groh

EMLYON Business School, Ecully, France

e-mail: groh@em-lyon.com

L. Hornuf

University of Bremen, Bremen, Germany

e-mail: hornuf@uni-bremen.de

L. Hornuf

Max Planck Institute for Innovation and Competition, Munich, Germany development of the markets. We conclude with suggestions for future ICO and CF research.

Keywords Entrepreneurial finance $\cdot$ SME financing · Crowdfunding $\cdot$ Initial coin offering $\cdot$ ICOs $\cdot$ Blockchain

JEL classifications $\mathrm{L} 26 \cdot \mathrm{G} 23 \cdot \mathrm{G} 24 \cdot \mathrm{G} 30$

\section{Introduction}

Technological development and regulation and the rise of social media had tremendous effects on the

\author{
L. Hornuf \\ CESifo, Munich, Germany \\ T. Vanacker $\cdot$ S. Vismara \\ Ghent University, Ghent, Belgium
}

T. Vanacker

e-mail: tomr.vanacker@ugent.be

S. Vismara

e-mail: silvio.vismara@unibg.it

T. Vanacker

University of Exeter Business School, Exeter, UK

S. Vismara

University of Bergamo, Bergamo, Italy 
entrepreneurial finance market. New players and new financial intermediaries have emerged that increase financing opportunities for entrepreneurial ventures (Block et al. 2018). Crowdfunding (CF) in its various forms has developed into a standard tool for raising seed capital in some industries, while new funding instruments, such as initial coin offerings (ICOs), ${ }^{1}$ have only recently become available and started to receive entrepreneurs' attention (Fisch 2019; Kher et al. 2020). Similar to the way in which CF has made its way into the toolbox of entrepreneurs, ICOs and similar offerings have the potential to shape the entrepreneurial finance markets of the future. However, these offerings also entail challenges. For example, ICOs are based on decentralized blockchain technology, which raises questions about international legal standardization, harmonization, and regulation (Huang et al. 2019).

This editorial and the accompanying special issue intend to increase our understanding of these two new segments of the entrepreneurial finance market. Although initially, CF and ICOs appear to be very similar in their characteristics and mechanisms, there are meaningful differences between the two funding tools. Entrepreneurs and investors need to understand these differences to use these funding methods in the most efficient way. The same applies to policymakers who are asked to define an appropriate regulatory framework for the two financing instruments.

This editorial aims to define and describe the two new types of matchmakers in the digital entrepreneurial ecosystem (Sussan and Acs 2017) and to structure them. $\mathrm{CF}$ and, more recently, ICOs have attracted much attention in the academic literature. These instruments are the topic of the majority of the most frequently cited papers published over the last 5 years in top entrepreneurship journals. The most cited paper published in Small Business Economics from 2015 (Vismara 2016) is on CF. Of the ten most frequently downloaded papers in 2019 that were published in Small Business Economics in 20172019, five are about $\mathrm{CF}$ and fintech. These papers received approximately 30,000 downloads.

Unlike in the more traditional entrepreneurial finance segments, such as the venture capital (VC) or initial public offering (IPO) market, the USA does not dominate. Some of the equity CF platforms with the largest transaction volume are based in Europe. This is partly

\footnotetext{
${ }^{1}$ We use the term initial coin offering (ICO) throughout the paper. This term includes so-called security-token offerings (STOs).
}

due to regulatory effects. Although the Jumpstart Our Business Startups (JOBS) Act, which was signed into law on April 5, 2012, introduced CF as a means for entrepreneurs to raise equity financing in the USA, these markets were ultimately regulated by the SEC starting in 2015 and became effective on May 16, 2016 (Cummings et al. 2019). By contrast, CF developed in Europe in 2012. Overall, the empirical setting of most papers on equity $\mathrm{CF}$ is Europe.

A call for papers soliciting submissions for this special issue was posted online in December 2017. Then, papers were selected for a special issue workshop at EMLYON Business School (France) on June 6, 2018. The Entrepreneurial Finance Conference (ENTFIN Conference) in Milan, Italy, followed in June 2018, with a special track dedicated to paper presentations for this special issue. Finally, we held the 6th Crowdinvesting Symposium on July 20, 2018, at the Max Planck Institute for Innovation and Competition in Munich, Germany. These events were attended, in total, by more than 200 entrepreneurial finance scholars. All submissions underwent a double-blind review process that led to the selection of nine papers that qualified for publication in this special issue.

The remainder of this editorial is as follows. We first define and describe the two new segments of the entrepreneurial finance markets. Subsequently, we compare both segments focusing on the respective stakeholders, market mechanism, regulatory environment, and development. Subsequently, we summarize the nine contributions selected for the special issue, provide an overall research outlook, and provide a brief conclusion.

\section{How do ICOs compare to CF?}

\subsection{Definitions}

We define ICOs as in Fisch et al. (2019) and Huang et al. (2019). An ICO is an event where a venture sells tokens to a crowd using distributed ledger technologies (DLTs), such as blockchain technology. Tokens are units of value and can provide utility (utility tokens) or resemble securities (security tokens). The former offers the right to use the products or services of the venture, whereas the latter makes the buyer a debt or equity holder and allows her to participate in the value increase of the venture or provides other financial incentives (e.g., interest or preferred dividends). Accordingly, we 
distinguish between ICO utility and security token issues. The latter are also referred to as security token offerings (STOs). CF is defined as a form of fundraising, via the Internet, whereby people pool money, usually small individual contributions, to support a particular goal (Ahlers et al. 2015). Additionally, for CF, we focus on the distinction between reward-based and equity $\mathrm{CF}$.

We differentiate the two fundraising instruments using four questions: Who are the stakeholders of the market segments? How do the markets function? What is the regulatory environment, and finally, how did these market segments emerge and develop? Table 1 summarizes this comparison. ${ }^{2}$

\subsection{Who are the stakeholders?}

\subsubsection{Proponents}

Who are the proponents in CF and ICOs? A key difference between reward-based and equity $\mathrm{CF}$ is that reward-based campaigns can be launched by private individuals or firms. Equity CF campaigns exclusively originate from firms (Cumming et al. 2019a; Vismara 2018).

Proponents in both reward-based and equity CF operate in a wide range of traditional sectors. For example, most projects on Kickstarter (a reward-based CF platform) are related to games, design, technology, film and video, music, fashion, publishing food, and art. ${ }^{3}$ Similarly, projects on Seedrs (an equity CF platform) often relate to food and beverage, finance and payments, home and personal, software as a service, platform as a service, and travel, leisure, and sports. ${ }^{4} \mathrm{CF}$ projects should not be overly complex because "the crowd" has low incentives and capabilities to perform in-depth due diligence (Cumming et al. 2019c). Consistent with this view, Chan and Parhankangas (2017) show that more radically innovative Kickstarter projects-which are riskier to develop and more difficult for the crowd to understand - exhibit less favorable funding outcomes.

Similar to reward-based CF, utility token ICOs can be initiated by firms or individuals. Analogous to equity $\mathrm{CF}$, STOs are limited to firms because they relate to the issuance of debt or equity. Similar to CF, ICOs take

\footnotetext{
${ }^{2}$ See Ackermann et al. (2020) for a similar comparison.

${ }^{3} \mathrm{https} / / / \mathrm{www} . k i c k s t a r t e r . c o m / h e l p / s t a t s ~(a c c e s s e d ~ D e c e m b e r ~ 6,2019)$.

${ }^{4}$ See https://learn-cdn.seedrs.com/wp-content/uploads/2018/09 /21134223/Seedrs_-PortfolioUpdate_Autumn2018.pdf (accessed December 6, 2019).
}

place in a broad range of sectors. However, contrary to $\mathrm{CF}$, ICOs often relate to financial services, high-tech business services, platform development, cryptocurrencies, and smart contracts (Adhami et al. 2018). ICO business models are often based on blockchain technology and are therefore more complex. ICOs also take place in more traditional sectors, such as entertainment, health, food, and education. However, these types of ICOs are rare and small in terms of the funding amounts raised. ${ }^{5}$

\subsubsection{Backers}

Who are the backers of CF and ICOs? In reward-based $\mathrm{CF}$, the crowd provides funding to a campaign in exchange for a promise of a future reward (Mollick 2014). In equity $\mathrm{CF}$, the crowd injects money via an issue of equity (Ahlers et al. 2015). Contrary to reward-based $\mathrm{CF}$, it is not the interest in a product or service but the expected financial returns that are the primary drivers for backer engagement in equity CF (Ahlers et al. 2015; Cumming and Johan 2013).

Reward-based CF is broadly accessible to everyone. However, on equity CF platforms, access can be limited to accredited investors only. Even if there is no accreditation requirement, the investment limits can vary based on the income or net worth of individuals, contingent on the prevailing legislation.

Members of the crowd are not only private individuals. There is evidence that both professional venture capitalists (VCs) and semiprofessional angel investors are active members of equity $\mathrm{CF}$ platforms. For example, Kleinert et al. (2020) show that out of 221 firms running equity $\mathrm{CF}$ campaigns on Crowdcube in 2017 and 2018, almost 50\% raised previous funding. This prior funding was raised from business angels (for 66 firms), from VCs (for 33 firms), on CF platforms (for 31 firms), and from government grants (for 19 firms). Ventures that did not raise prior capital show a success rate of $41 \%$ compared with a $72 \%$ success rate for ventures that previously received external capital. Despite these important links between equity $\mathrm{CF}, \mathrm{VC}$, and angel investment, the literature remains largely segmented. We know relatively little about why business angels and VCs start selecting firms through equity CF platforms and not via their usual deal flow channels. Given that VCs anticipate finding low-quality rather than high-

\footnotetext{
${ }^{5}$ See https://icobench.com/stats (accessed December 6, 2019).
} 


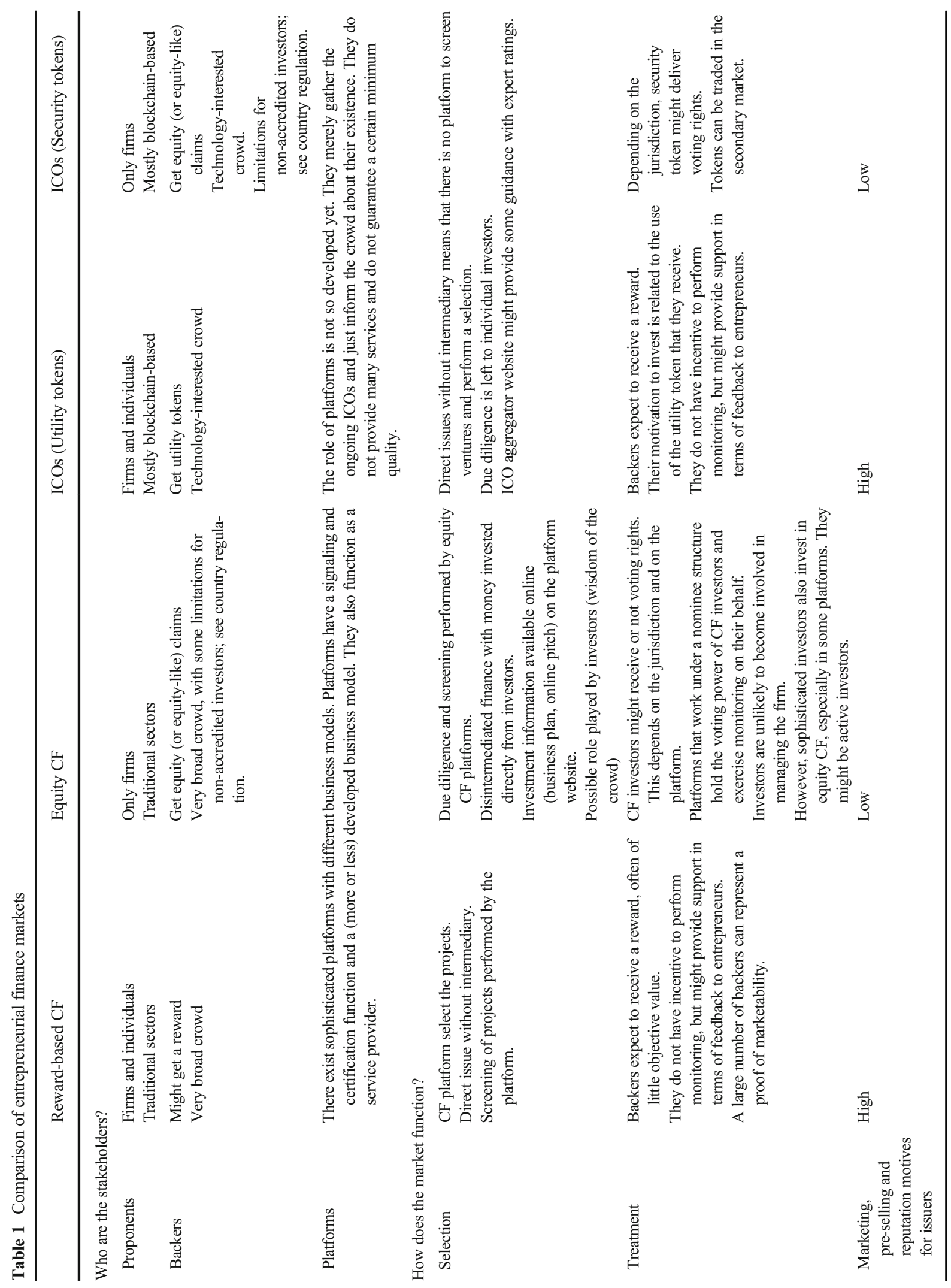


quality start-ups on CF platforms (Mödl 2019), we are puzzled by which types of VCs are screening deals on CF platforms, whether and why they push their portfolio firms to equity CF platforms, and how the crowd, VCs, and business angels interact post-investment.

In a utility token issue, a venture sells tokens with the promise that these tokens will have some utility in the future. In an STO, the tokens that are sold are deemed securities (equity or debt). This is similar to the difference between reward- and equity-based CF. However, there is an important difference. Utility tokens are more easily traded compared with rewards from CF campaigns. Therefore, utility tokens can attract financially motivated investors. Recent evidence by Fisch et al. (2019) shows that technological motives are the most important investment rationale for ICO investors, followed by financial and ideological motives. Accordingly, ICOs are expected to attract more technologyinterested investors compared with CF campaigns. VCs also participate in ICOs. ${ }^{6}$ This observation raises questions about the types of VCs that subscribe to ICOs and their rationale.

\subsubsection{Platforms}

What is the role of platforms as intermediaries in $\mathrm{CF}$ versus ICOs? Platforms and their design play an important role in the CF market segment (Belleflamme et al. 2015). The platforms are the marketplaces that match demand with supply of funds and provide facilities for the exchange of information among investors and entrepreneurs. Some of the platforms aim to ensure a certain level of quality of the CF projects and to reduce information asymmetries (Belleflamme et al. 2015). To avoid the presence of suspect investments and to guarantee a certain quality of the advertised projects, some platforms force the project initiators to be transparent about their venture and the entrepreneurial team. Moreover, some platforms introduce an application process where project initiators need to meet certain criteria and provide particular information to be eligible to be listed on the platform. The specific requirements differ among platforms and depend on the particular CF type. For example, equity CF platforms require a more comprehensive description of the business model, the venture team, and the financial characteristics, and they some-

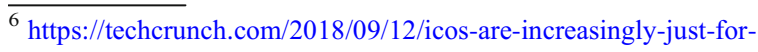
venture-capitalists/ (accessed December 6, 2019)
} 
times conduct background checks. In addition to signaling and certification function, the platforms offer clearing services. These services help reduce transaction costs and avoid ethical problems with project initiators.

The role of ICO platforms is not yet well defined. There are websites to inform potential investors about ongoing ICO campaigns. Such websites could be considered platforms or marketplaces bringing together supply and demand. However, unlike typical CF platforms, these websites do not act as gatekeepers that aim to maintain a certain project quality. These websites also do not provide direct matching or clearing services. Transaction closing and payment processing is decentralized via blockchain technology. In fact, the original idea of ICOs was to not have centralized authorities matching supply with demand but to use technology that allows matching in a decentralized network. To summarize, platforms and the associated network effects play an important role in CF but are currently of minor importance in ICOs.

\subsection{How do the markets function?}

\subsubsection{Selection of projects}

In most cases, there is no meaningful difference in the pre-process of selecting projects that qualify for $\mathrm{CF}$ or ICOs. Potential CF projects are posted online on a platform. Thus, the portals perform a selection. Some portals claim to perform an accurate screening and due diligence, while others define their role as a facilitator and clearing house. For example, the US platform Wefunder reports on its website that they “....don't want Wefunder to be a gatekeeper that picks and chooses which ideas are worthy of funding. That's for you to decide." ${ }^{, 7}$ Nevertheless, most of the platforms worry about their reputational capital and use selection criteria to choose projects.

The platforms are heterogeneous with respect to funding models due diligence practices, offering duration, services offered, corporate governance and offering-related conditions, and finally, their fees. There are only a few papers on the heterogeneity of CF platforms. Rossi and Vismara (2018) describe the regulation and development process of equity $\mathrm{CF}$ in France, Italy, Germany, and the UK. Using a sample

\footnotetext{
${ }^{7}$ https://help.wefunder.com/getting-started-for-investors (accessed December 6, 2019)
}

of 127 platforms in these countries, these authors document which services are offered to proponents before, during, and after the campaigns. These authors find that a higher number of postcampaign services offered by the platforms increase the annual number of successful campaigns. Services offered before and during campaigns do not attract more campaigns to the platforms. Rossi et al. (2019) focus on the corporate governance aspects in equity $\mathrm{CF}$. The cross-platform analysis reveals a large variety of corporate governance mechanisms, particularly with regard to the voting rights of investors. Some platforms assign voting rights to individual investors, some work under a nominee structure, and some require the involvement of accredited investors to list offerings. Comparing platforms globally, these authors find that the assignment of individual voting rights is associated with lower chances of success of the platforms, whereas the delivery of pooled voting rights is not significant. Cumming et al. (2019c) evaluate the factors associated with platforms' compliance expenses and their due diligence application. These authors find that due diligence is related to legislation requirements, platform size, and CF campaign type or complexity.

Despite these differences, all CF platforms act as direct intermediaries between potential investors and project proponents. As such, CF platforms govern the fundraising process by setting their particular platform rules in compliance with the regulation of the country in which they are based. ICO markets function differently. ICO markets provide a disintermediated way to raise capital. ICOs are not listed on platforms. There are websites that provide aggregate information and guidance, including expert ratings. However, ICOs are direct issues without intermediaries. As such, screening and due diligence are entirely left to individual investors.

\subsubsection{The impact of monitoring and value added by funders}

It is in an investor's interest to perform an ex-ante selection among potential investments and to ex-post monitor and provide value-adding services to an investee. With regard to the impact of monitoring and value adding, the importance of the participation of private investors in CF campaigns or ICOs is arguably lower than the importance of the participation of professional VCs or semiprofessional business angels. Individual private investors presumably lack the expertise 
and incentive to maintain close relationships with the management of the firms that they back. Furthermore, private investors usually do not have the particular contractual information and control rights that professional investors and business angels require as prerequisites for an investment. Nevertheless, while backers in rewardbased CF expect only to receive a reward, often of little objective value, investors participating in equity $\mathrm{CF}$ campaigns and in STOs are concerned with the performance of their investments. However, unlike with reward-based $\mathrm{CF}$, the backers of utility token issues are also interested in the financial performance of their investment. Utility tokens are tradable and exposed to price fluctuations, which attracts financially motivated and speculative investors. Actors on reward-based CF platforms, in turn, are expected not to have financial and, thus, monitoring interests but rather might provide support to entrepreneurs in terms of feedback. If a campaign has numerous supporters, this can be interpreted as proof of marketability of the product or service that the proponents aim to deliver.

Equity $\mathrm{CF}$ investors sometimes obtain voting rights. Obtaining voting rights is contingent on the jurisdiction and the platform. Some platforms operate under a nominee structure. These platforms hold the voting power of the crowd and exercise monitoring and voting on the crowd's behalf. Other platforms assign voting rights directly to investors. There are some equity CF platforms on which sophisticated investors participate. These investors are usually particularly concerned about their voting and control rights (Cumming et al. 2019b). Nevertheless, despite the reluctance of CF investors to become actively involved in controlling and managing their investees, they are, as other shareholders, interested in their future proceeds.

\subsubsection{Marketing-and innovation-related benefits}

$\mathrm{CF}$ research emphasizes that project initiators regard $\mathrm{CF}$ as more than a financial source. Project initiators are also attracted by the marketing and innovation-related aspects of CF (Da Cruz 2018; Block et al. 2018). By setting up a CF campaign, the initiator gains valuable information from potential future customers about desirable product features, product pricing, and product distribution strategies. Moreover, founders have the chance to introduce the product to the market and its customers without even having produced it yet. This early introduction creates awareness, helps to build and establish a brand, and reduces the uncertainty related to the marketing of new and innovative products.

Backers have different roles and functions. Backers are not only early investors but also a valuable source of information. Backers may even turn into product promoters and opinion leaders helping to spread the word about the CF product and its features. This practice helps the project initiators cross the chasm from the group of early adopters to the mass market. Such marketing-related benefits of $\mathrm{CF}$ exist primarily with reward-based campaigns and to a lesser extent with equity CF. To date, little research exists about the marketing-related benefits of ICOs. However, given the similarities and the analogies between rewardbased CF and utility token-based ICOs, we would expect marketing-related benefits to also play a significant role in utility token issues. Marketing-related benefits might even be of higher importance for utility token ICOs given that tokens are a sort of presale of a blockchain-based product or service.

\subsubsection{Fraud resistance}

The emergence of new entrepreneurial finance market segments that connect entrepreneurs and nonprofessional investors globally via an Internet connection raises concerns about low-quality projects and fraud. Mollick (2014) shows that fraud is rare in reward-based CF, with only $2.3-3.6 \%$ of Kickstarter projects showing indications of potential fraud. Cumming et al. (2019d) provide an in-depth analysis of fraud in reward-based CF and conclude that "[...] CF fraud is a rare event, despite apparent widespread skepticism by the media, politicians, and regulators." Hence, the CF community is often able to detect cases of fraud, and online marketplaces may facilitate such detection. To varying degrees, CF platforms also perform due diligence before projects are listed on the platform (Cumming et al. 2019c). However, such due diligence is more prominent on larger platforms, notably on equity and lending $\mathrm{CF}$ platforms.

Contrary to $\mathrm{CF}$, ICOs are clearly less fraud resistant. Industry reports suggest that $80 \%$ of the number of ICOs could be identified as scams. ${ }^{8}$ Nevertheless, these reports highlight that only $10 \%$ of the overall ICO fundraising volume was allocated to later identified

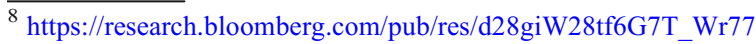
aU0gDgFQ
} 
scams and the majority of these funds actually went to three projects. In addition to these three projects, identified scams collected just $\$ 30$ million or approximately $0.3 \%$ of all-time ICO fundraising. Hornuf et al. (2019) provide a more detailed analysis of fraud in ICOs. These authors suggest that in contrast to the findings for $\mathrm{CF}$ (Cumming et al. 2019d), the extent of information disclosure offers little opportunity to identify possible fraud cases. Contrary to utility token issues, security tokenbased ICOs distribute securities representing financial claims on assets. Accordingly, STOs are governed by security law and protected by collateral. Thus, STOs provide additional insurance against fraud and manipulation.

The differences in fraud levels and fraud detection in the new entrepreneurial finance market segments raise questions about whether and why individuals are better at identifying scams in some markets relative to others and about the role of platform due diligence versus the wisdom of the crowd. This question becomes increasingly important because, more recently, ICOs have been conducted through exchanges, which can have a selection function. Such issues are called initial exchange offerings (IEOs).

\subsection{How are the markets regulated?}

The regulation of $\mathrm{CF}$ and ICOs is largely contingent on the offering characteristics. In reward-based CF, issuers typically offer consumers the ability to prepurchase a product or service. If the campaign creator has been fraudulent, many jurisdictions provide common law or general civil law actions, which allow backers to recover what they initially pledged. The same actions can be taken if a fraudulent issuer created a utility token as part of an ICO that was meant to prepurchase a product or service on a newly created platform. Some countries have specific legislation on the new entrepreneurial finance markets. For example, in the USA, the Federal Trade Commission (FTC) has jurisdiction when goods are sold via a CF or ICO platform. Government agencies and courts can also impose monetary penalties on fraudulent campaign creators. When financial securities are sold, the general securities laws apply, which allows investors and the Securities and Exchange Commission (SEC) to bring legal actions. What constitutes a security depends on how the offering is structured. In the USA, securities are defined under the Securities Act $\S 2(a)(1)$ or the Exchange Act $\S 3(\mathrm{a})(10)$. Whether an ICO constitutes a security largely depends on the business model of the issuer and is usually determined by applying the Howey test; that is, an offering involves a security if investors invest their money in a common enterprise and are led to expect profits solely from the efforts of the promoter or a third party. Donation- and reward-based $\mathrm{CF}$ do not involve the sale of securities, while equity CF and STOs do, by definition.

Most importantly, in many jurisdictions, issuers in equity CF campaigns and STOs must inform investors about the offer by means of a securities prospectus. Drafting such a prospectus is costly, and issuers on equity CF platforms might be reluctant to pay the costs of drafting such a prospectus. For that reason, regulators around the world have implemented exemptions from the requirement to draft a securities prospectus for small offerings (Hornuf and Schwienbacher 2017). Given that STOs raise larger amounts of capital on average, the need to exempt issuers from the requirement to draft a securities prospectus might be less severe. Moreover, because fraud is more prevalent in ICOs, investor protection can be improved by an appropriate market design. In this context, Hornuf et al. (2019) require sophisticated investors and platforms to certify the quality of ICO issuers. This requirement has proven to be helpful on equity $\mathrm{CF}$ platforms where such certifications are voluntary.

An alternative investor protection measure is to limit the individual amount at risk in a single issue or the overall market. Comparable regulation was passed in many jurisdictions for equity $\mathrm{CF}$ but not for rewardbased CF. ICO investors might be subject to those limits once a regulation passes in the future. An individual's amount at risk on equity $\mathrm{CF}$ platforms can be restricted contingent on the investor's freely available assets and monthly net income. In the USA, unsophisticated investors may invest up to US\$2000 but are never allowed to invest more than US $\$ 100,000$, independent of their annual income and net assets.

Reward-based CF and ICOs rely on disintermediation. However, for the other new entrepreneurial finance market segments, regulation of intermediaries exists and differs significantly across jurisdictions. In the USA or Germany, among other jurisdictions, equity $\mathrm{CF}$ issuers can only benefit from the exemption of the prospectus requirement if they tap the market through such an intermediary. In France, for example, platforms need to obtain a license from the securities regulator because they are considered financial intermediaries and are 
therefore subject to a specific set of rules (Hornuf and Schwienbacher 2017). In Germany, by contrast, rewardand equity-based CF platforms are generally only lightly regulated under trade law. In some jurisdictions, platforms are required to file with a register, while in others, they are not. Little research exists on how regulation affects the quality of CF and ICOs.

Finally, the contract types differ largely among the different forms of CF and ICOs. In the case of rewardbased CF and utility token offerings, consumers often prepurchase a product or service, which implies that they strike a contract under trade law. In equity CF and security ICOs, investors hold rights in a corporation by holding financial securities or other forms of investments. While in the early days of ICOs, the issuers sometimes claimed that ICOs constituted a "new" and "unregulated" asset class, regulators around the world have now made clear that ICOs can constitute securities, and a white paper is not considered a substitute for a securities prospectus. ${ }^{9}$

\subsection{How did the markets emerge and develop?}

CF markets have shown fast growth, although doubledigit growth rates have slowed down over time. Reward-based CF platforms, such as Indiegogo and Kickstarter, emerged in 2008/2009. The cumulative amount of funding pledged to Kickstarter projects, for example, was approximately $\$ 276$ million by July 2012 , $\$ 1$ billion by March 2014, $\$ 2$ billion by October 2015, $\$ 3$ billion by April 2017, and over $\$ 4$ billion by January 2019. ${ }^{10}$ The UK equity CF market grew from $£ 84$ million in 2014, to $£ 245$ million in 2015 , to $£ 272$ million in 2016, and to $£ 333$ million in 2017 . $^{11}$ The outlook is that the global CF market will exhibit slower but steady growth over time. ${ }^{12}$

Contrary to CF markets, ICO activity has seen sharper growth and, recently, also rapid decline (Masiak et al. 2019). For example, the first ICO (i.e., Mastercoin) emerged in July 2013 (Fisch 2019). After very little ICO activity for the rest of 2013, 2014, and 2015, the

\footnotetext{
$\overline{9}$ See https://www.sec.gov/litigation/investreport/34-81207.pdf. (accessed December 6, 2019)

${ }^{10}$ See https://www.statista.com/statistics/310218/total-kickstarterfunding/ (accessed December 6, 2019).

${ }^{11} \mathrm{See}$ https://www.jbs.cam.ac.uk/fileadmin/user upload/research/centres/alternative-finance/downloads/2018-5th-ukalternative-finance-industry-report.pdf (accessed December 6, 2019).

${ }^{12} \mathrm{See}$ https://www.statista.com/outlook/335/100 /crowdfunding/worldwide (accessed December 6, 2019).
}

ICO market exhibited a jump in 2017, when entrepreneurs raised an estimated $\$ 6.5$ billion. In 2018, an estimated $\$ 21.6$ billion was raised. However, the data until October 2019 suggest that the ICO market significantly cooled because only $\$ 3.2$ billion had been raised. $^{13}$

Overall, CF and ICO markets exhibit significant differences in their development over time and volatility with respect to their volumes. It would be interesting to analyze why these market segments have developed differently.

\section{The papers in this special issue}

The descriptions of new entrepreneurial finance markets above suggest to open questions and requirements for further research. These open questions were the motivation of a public call for papers for this special issue of Small Business Economics on CF, blockchain technology, and ICOs. After a double-blind peer review process, nine papers qualified for publication in this special issue. These papers are summarized in the subsequent section. One paper addresses a crosslink of new entrepreneurial finance markets, namely, fintechs providing various financing sources for young ventures. Four papers focus on various questions related to CF. Three papers elaborate on ICOs. These eight papers are empirical. The ninth paper is a theoretical contribution and discusses blockchain technology in relation to smart contracts. The research questions, theoretical framework, empirical settings, and key findings of the special issue papers are presented in Table 2.

\subsection{Fintech clusters}

Industries are geographically concentrated, and it is questionable why the degree of this concentration is so large. Marshall (1920) argues that benefits of geographic clustering reflect the gain of reduced transport cost and emphasizes three types of such cost: the costs of moving goods, people, and ideas. Firms locate near suppliers and customers to reduce shipping costs. A second reason to agglomerate is to take advantage of scale economies resulting from a large labor pool. Third, the speed of the flow of ideas is a criterion for firms to

\footnotetext{
${ }^{13}$ See https://www.coinschedule.com/stats (accessed December 6, 2019).
} 


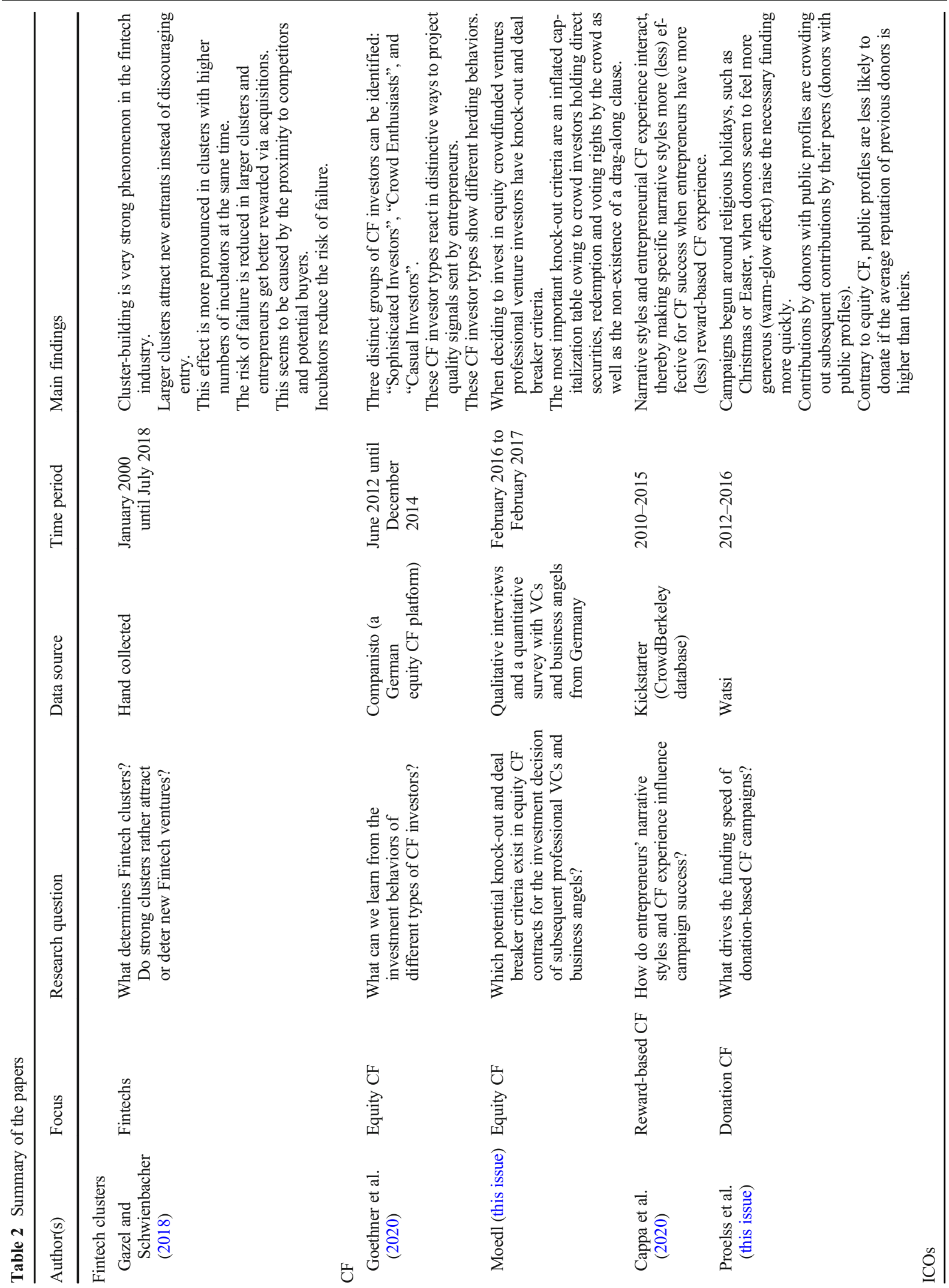




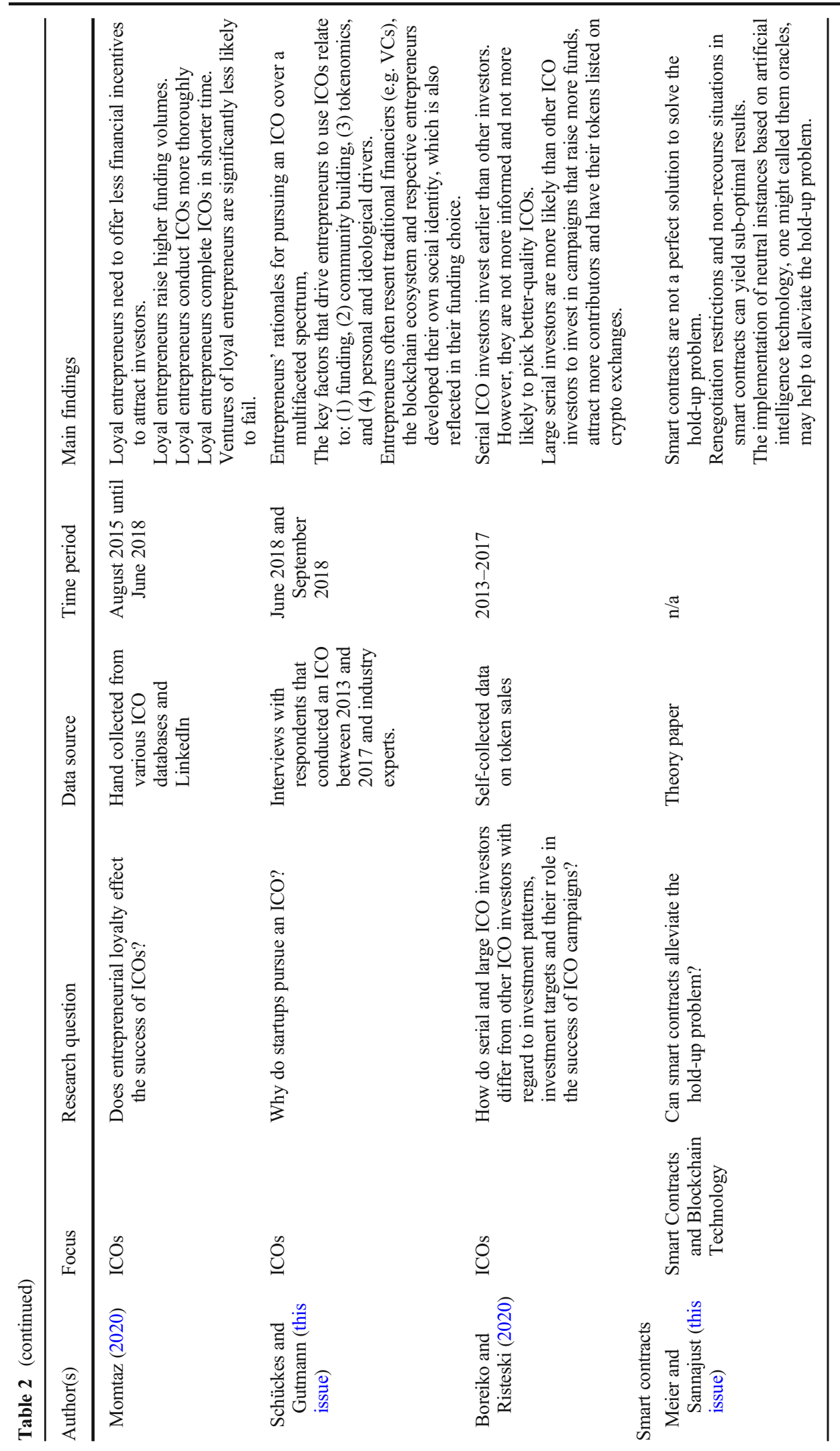


collocate, as agents can learn skills more quickly from each other in an industrial cluster. Ellison et al. (2010) provide strong support for these three drivers to be important for the explanation of industrial agglomeration. Audretsch and Feldman (1996) elaborate on the spatial distribution of innovation and potential spillover effects. These authors conclude that industry sectors where knowledge spillovers are more likely, i.e., where industry R\&D, university research, and skilled labor are most important, have a greater tendency to cluster than sectors where this is not the case. Feldman (1994) finds that the effect is more pronounced for small firms, while Acs and Audretsch $(1988,1990)$ highlight that small firms are the major driver of innovation. Acs et al. $(1992,1994)$ reveal that $R \& D$ expenses by private corporations and universities spill over for third-party firms to exploit. Under these circumstances, we witness geographic agglomeration and new venture creation, especially in intellectual and innovative centers where a strong academic community is present at the same time. The literature often refers to Silicon Valley as a well-known example, as described in Saxenian (1996).

The paper by Gazel and Schwienbacher (2018) elaborates on fintech clusters in France. The focus on a relatively new and knowledge-intensive industry that is free of the physical transport of goods provides a great identification strategy to verify Marshall's (1920) theory. Since fintechs operate independently of their location via new media channels and web technology, the driving forces of cluster building must be reduced to transfer talent and the exchange and spillover of new ideas. Gazel and Schwienbacher (2018) examine the impact of specific socioeconomic drivers on the formation of fintech clusters. These authors raise the interesting research question of whether large fintech clusters encourage additional start-up activity or if the effect is the opposite. A greater number of incumbents could increase competition and thus deter new entrants. Along the same line, cluster building could affect the harvesting capabilities of entrepreneurs. Access to finance and, related to that, entrepreneurial exit opportunities could be different in large fintech clusters compared with those in regions with little collocation. The authors gather data for 972 fintech start-ups located in France. The data span the period 2000 to 2018 and include all major sectors within the fintech industry. The paper finds the following important results. Cluster-building is a very strong phenomenon in the fintech industry. Larger clusters attract new entrants instead of discouraging entry. The effect is more pronounced in clusters with higher numbers of incubators at the same time. The risk of failure is reduced in larger clusters, and entrepreneurs receive higher rewards via acquisitions. The authors note that this phenomenon seems to be caused by the proximity to competitors and potential buyers. Finally, incubators reduce the risk of failure.

In summary, Gazel and Schwienbacher (2018) reveal that clustering is still an important phenomenon, perhaps more important than ever, even in decentralized and information-driven technology that is free of any physical transfer of goods. The decision regarding where to place a venture's headquarters needs to be made with care and with consideration of the benefits of collocation with peers. Public policy to support cluster-building and to establish incubator programs seems warranted.

\section{$3.2 \mathrm{CF}$}

The immanent information asymmetry between entrepreneurs and investors and the resulting agency cost are also the subject of the paper by Goethner et al. (2020). Since crowd investors are usually less experienced in evaluating business plans compared with professional investors, the problem of information asymmetry is especially pronounced on equity CF platforms (Vismara 2019). The paper elaborates on a set of 16,666 investments into 28 projects made by 7474 investors on Companisto, which is a German CF platform. The authors perform a cluster analysis, sorting investors based on similarities in their previous investment histories. These authors aim to determine typical investor profiles and investment strategies and to distinguish three motivations among $\mathrm{CF}$ investors: financial, social, and community benefits. The authors also capture the experience and degree of sophistication of their sample of investors. In this way, the authors can identify three distinct groups that they name "sophisticated investors," "crowd enthusiasts," and "casual investors." These CF investor types react in distinctive ways to project quality signals sent by entrepreneurs. They also show different herding behaviors contingent on the information received about the investment decisions of fellow investors. The paper contributes to the growing literature of how different audiences acquire and interpret distinct signals differently (Vanacker and Forbes 2016).

Goethner et al. (2020) formulate hypotheses about the relation between the reception of human and 
entrepreneurial quality signals and the investment decisions of the distinctive groups of CF investors. The hypotheses notably build on Becker (1964), Ahlers et al. (2015), Cumming et al. (2020), Piva and RossiLamastra (2018), Bapna (2019), Epstein and Schneider (2008), and Vismara (2018). The insight gained into the heterogeneity of CF investors, their motivations to fund campaigns, and their response to quality signals is important for the design of CF platforms and for entrepreneurs. Policymakers need to trade off investor protection against their interest to stimulate start-up activities and should focus on setting appropriate information standards. For example, policymakers can require improving the platform design to alleviate information transmission from knowledgeable CF investors to lessinformed investors. The findings of Goethner et al. (2020) confirm that sophisticated investors are a part of the crowd and that they are the active investors on these platforms. Regulation could create the prerequisites for knowledge spillovers. These spillovers would be beneficial for entrepreneurs and the investment community alike.

Moedl (this issue) investigates potential contractrelated deal-breaker terms of professional venture investors when deciding whether to invest in equity crowdfunded ventures. Using a mixed method approach of qualitative interviews and a quantitative survey with VCs and business angels from Germany, Moedl finds that such deal-breaker terms indeed exist and influence the investment decisions of professional venture investors. An example of such terms is the nonexistence of a drag-along clause: an inflated capitalization table owing to crowd investors holding direct securities and redemption and voting rights by the crowd. The paper contributes to the growing literature of how CF can be combined with other sources of entrepreneurial finance (Block et al. 2018; Drover et al. 2017).

Signaling theory (e.g., Connelly et al. 2011; Spence 1973) has served in the CF context to model how proponents can signal unobservable quality to investors. When proponents signal their high quality (e.g., through human, social or intellectual capital), it reduces informational asymmetry and therefore increases the success of CF campaigns (Ahlers et al. 2015). Signaling theory has largely focused on those signals that are assumed to be both observable and costly to imitate by low-quality firms, but signals can differ in the extent to which they are correlated with unobservable firm quality (e.g., Colombo et al. 2019; Vanacker et al. 2019). Indeed, a largely separate stream of literature has focused on entrepreneurial storytelling, which sometimes "re-present" the facts, and indicates that properly crafted stories can also serve as informational cues that foster entrepreneurial resource acquisition (e.g., Martens et al. 2007).

Cappa et al. (2020) connect these two streams of the literature using the reward-based CF context. Specifically, these authors examine how two main narrative styles - "results in progress" (RIP), emphasizing the quality and features of the product-reward, and "ongoing journey" (OJ), emphasizing the values and vision that inspired the undertaking of the entrepreneurial project-influence fundraising. These authors further examine the role of previous reward-based CF experience and how such experience interacts with narrative styles to influence fundraising. The results of this study indicate that backers pledge more money to CF campaigns that are communicated through RIP narrative styles rather than OJ styles. Moreover, in addition to the positive effect of previous experience, these authors find that entrepreneurs with extensive experience in reward-based CF attract more pledges by adopting OJ narratives rather than RIP narratives.

Proelss et al. (this issue) focus on healthcare $\mathrm{CF}$, which is defined as a method to raise funds for medical expenses or treatment by a group of mostly small donors through an open call for funding on Internet-based platforms. CF platforms (and social entrepreneurship more broadly) play an increasingly important role in addressing large societal challenges, including lack of access to essential healthcare services. Using data from Watsi. org, these authors find that campaigns that started near religious holidays, such as Christmas or Easter, raise the necessary funding more quickly. Interestingly, contributions by donors with public profiles crowd out subsequent contributions by their peers (other donors with public profiles). Contrary to equity $\mathrm{CF}$, these authors further find that donors with public profiles are less likely to donate if the average reputation of the previous donors is higher than theirs. Overall, the theoretical framework the authors have developed and empirically tested for donation-based CF differs substantially from existing frameworks and previous evidence tailored to reward-based and equity $\mathrm{CF}$. These findings also have important practical implications because they provide new 
insight into how to increase donations and enhance overall social entrepreneurship.

\subsection{ICOs}

In ICOs, entrepreneurs raise external capital through the issuance of blockchain-based tokens. Ideally, transaction costs are low, investor outreach is global, and coins can be traded in a liquid secondary market after issuance. On the other hand, and typical for the entrepreneurial finance context, ICOs are characterized by a large degree of information asymmetry between issuers and investors, thus yielding a substantial risk of agency problems and cost. Therefore, ICO ventures need to send strong quality signals to the ICO investment community to secure fundraising. However, it is not clear what kinds of signals are appropriate for this purpose. Momtaz (2020) examines a proxy for agency conflicts that is commonly used in social psychology, namely, loyalty. Momtaz measures the loyalty of entrepreneurs by the number of previous positions they held in proportion to their cumulative job experience in years. The overarching hypothesis is that their loyalty positively impacts ICO success in terms of underpricing, gross proceeds, operational efficiency, and entrepreneurial failure.

Loyalty affects decision-making, and therefore the manifestation of agency costs, in different ways. Akerlof and Kranton (2005) model this as follows. First, loyalty has an influence on an individual's utility gain. Second, loyalty affects the subjective probabilities of possible states of the world, which are used for decision making. Overall, the positive impact of loyalty on agents' utility gain is expected to reduce agency costs from asymmetric information in the ICO market. The rationale is that entrepreneurs who have demonstrated loyalty in the past signal, on average, quality relationships with their former principals. This finding is interpreted as a lower potential to cause future agency costs and should therefore attract investors.

Momtaz (2020) collects data for more than 2000 ICOs from several appropriate platforms and gathers CEO information from LinkedIn. Momtaz finds that loyal entrepreneurs need to offer fewer financial incentives to attract investors and raise higher funding volumes. Loyal entrepreneurs also conduct ICOs more thoroughly and complete them in a shorter time frame. In addition, the investors' belief that loyal entrepreneurs cause less agency costs proves correct in the long term; ventures of loyal entrepreneurs are significantly less likely to fail prematurely.

The paper contributes to the economics of loyal behavior, e.g., Demsetz (1962) and Akerlof (1983). More recent work has focused on the effect of loyalty on financial decision-making. Cohen (2008) reveals that individuals' portfolio choices are largely determined by their loyalty to their employers and related corporations. The focus of Momtaz (2020) is in the opposite direction: the loyalty of entrepreneurs towards investors. This relation has not been examined before.

While prior work has focused on the investment rationale for ICO investors, i.e., the supply side of the market (Fisch et al. 2019), Schückes and Gutmann (this issue) focus on the motivations of startups to pursue ICOs, i.e., the demand side of the market. Using interview-based data, these authors find that entrepreneurs' rationales for pursuing an ICO cover a multifaceted spectrum, including (1) funding, (2) community building, (3) tokenomics, and (4) personal and ideological drivers. Contrary to traditional financial theories that often focus on financial value maximization of financing decisions, these authors report that the blockchain ecosystem and respective entrepreneurs developed their own social identity, which is also reflected in their funding choice.

Boreiko and Risteski (2020) compare serial and large ICO investors with other ICO investors. Using a large self-collected dataset on token sales ranging from 2013 to 2017, these authors find that the average serial ICO investor invests earlier than the other ICO investors. However, serial investors are not more informed than other ICO investors, per se, and fail to choose better quality ICOs. The situation is different from large serial investors, who seem to have an information advantage over other ICO investors, as they are more likely to invest in more successful ICO campaigns. The paper contributes to the discussion of information asymmetries that exist in ICOs (Fisch 2019). The combination of investor size and investor experience seems to reduce such asymmetries. The paper also contributes to the discussion on the heterogeneity that exists within the group of ICO investors (Fisch et al. 2019).

\subsection{Smart contracts}

Contract theory, e.g., Jensen and Meckling (1976), explains the complex situation between two parties who do not have the same level of information (i.e., 
asymmetric information). Entrepreneurs constantly face this situation with respect to their stakeholders, which can yield the "hold-up problem." This problem is caused by the incomplete nature of contracts and was introduced in Williamson (1985), Grossman and Hart (1986), and Hart and Moore (1990). If a contract party has previously entered into a relationship with another party, the latter may try to maintain the relationship, reflecting the importance of the commitment it has made. The commitment is usually a substantial investment related to the procurement of the ability to deliver goods or services. A hold-up problem, therefore, leads to underinvestment and inefficiency in a relationship. A historical example from the 1920s may illustrate this problem in the most comprehensible way. The automotive supplier Fisher Body had an exclusive contract with the car manufacturer General Motors for body parts. The supplier had a monopoly in this specific market. An unexpected event significantly increased the demand for cars, exceeding all the forecasts stipulated in the contract. The supplier therefore took strong advantage of this development and forced General Motors to substantially increase the price they would pay for the additional parts produced.

According to Grossman and Hart (1986) and Hart and Moore (1990), the two economic actors in a contract have the freedom to renegotiate the terms of the contract they have already signed. However, since the surplus generated is shared according to Nash's equilibrium, both parties receive a lower return on investment, which, in turn, leads them to settle on a lower level of investment. In the end, the outcome is underinvestment. The best situation would be to settle an agreement where no party can interfere, that is, a negotiation-free contract. This practice would improve trust and eliminate opportunistic behavior. Nevertheless, one evident problem in practice results from first-time contractual relationships. Cressy (1992) shows that agents are exposed to cognitive bias, which affects their behavior in such first-time relationships. A promising and timely approach to address this problem seems to be the use of an IT protocol. This approach puts agreements into a standard without room for interference. Lindholm-Dahlstrand et al. (2019) propose blockchain technology that may help entrepreneurs avoid opportunistic behavior. Smart contracts, such as IT protocols, between two parties could solve the imperfections of traditional contracts because changing the code or modifying the contract conditions is impossible.
Meier and Sannajust (this issue) discuss whether smart contracts are indeed appropriate to avoid opportunistic behavior and to solve the hold-up problem. These authors develop a model based on Hart and Moore (1999) and Hart (2009) and elaborate on the key issue that the quality of a purchased product or service might not be verifiable to the buyer in a world based on blockchain technology using smart contracts. Since contract renegotiation in such an environment is impossible, a neutral authority, which they call "an oracle," needs to make a judgment about a successful delivery of a shipped item. This oracle could follow artificially intelligent algorithms and gain knowledge and experience about such judgments. The oracle can provide the buyer with a means of recourse in a world of complete contracts where recourse is otherwise impossible.

\section{Conclusion and avenues for future research}

This special issue on new markets for entrepreneurial finance with a strong focus on ICOs is the first of its kind. Prior research struggled to provide a clear distinction between ICOs and CF. Our editorial provides a detailed comparison of the two entrepreneurial finance market segments and intends to make a distinction. We show that although both market segments are crowdbased, they are fundamentally different with regard to the role of platforms and the motivations of the backers. It is important that entrepreneurs, investors, and policy makers understand these differences. Otherwise, the funding tools cannot live up to their full potential. When comparing the two funding tools, many ideas for future research emerged that we would like to share with the entrepreneurial finance research community. We group these ideas similar to the way in which we have structured our comparison of ICOs and CF above.

\subsection{Market stakeholders}

- What are the potential benefits and challenges of ICOs? Which types of entrepreneurs seek financing via ICOs? Which business models are funded and which are not? What is the role of intermediaries in ICOs?

- How do ICO investors value firms? How are ICOs priced? How do ICO and CF platforms select firms? How can ICO platforms or websites reduce 
information asymmetries and moral hazard problems, helping to develop a functioning ICO market and avoiding a market for lemons? On what dimensions do CF and ICOs compete?

- Who invests in ICOs, and who invests in CF campaigns? How diversified are these investors? Are they different from investors in "traditional" markets? How do companies decide to deliver voting rights in $\mathrm{CF}$ and ICOs? How do investors' motivations differ between ICOs and CF?

- What marketing-related benefits exist with $\mathrm{CF}$ and ICOs, and how do they differ between the two forms of entrepreneurial financing? How can project initiators obtain information from the crowd and use this information to improve their products or innovation, and how are they introduced to the market? Regarding ICOs, how can information about the product move from a niche segment of technology enthusiasts into a mass market of regular consumers?

- How does CF relate to crowdsourcing? Which types of relationships are generated in CF and blockchain transactions? What do investors do after an investment? Do they interact with the entrepreneurs they back?

\subsection{Market functioning}

- How do blockchain technology and cryptocurrencies change the entrepreneurial finance ecosystem? To what degree do ICOs and CF shift entrepreneurial financing preferences? What are the relationships between new and traditional entrepreneurial finance providers? Are these providers complements or substitutes?

- The existing literatures on CF and ICOs focus primarily on the success factors of the campaigns. The ultimate goal of CF and ICOs, however, is to build an enduring business. With the exceptions of Fisch and Momtaz (2019) as well as Howell et al. (2018), we know little how ICOs influence real business outcomes. What happens after the ICO and CF offerings? How do ICOs and CF interact in this regard?

- How do herding effects differ between CF and ICOs? Regarding ICOs, what is the role of Bitcoin and Etherium in creating herding effects (Masiak et al. 2019)?
4.3 Market regulation

- Are ICOs a real financial innovation, or do they simply help issuers circumvent securities regulation? What is the nature of the potential innovation? How should securities regulators react to different kinds of ICO offerings?

- How and to what degree should regulation adapt to this changing entrepreneurial finance environment? Which countries attract ICOs and create a favorable regulatory environment? How can the risk of bubbles be limited?

\subsection{Market emergence and development}

- What are the factors and antecedents that spur the growth and development of ICOs versus CF? What is the role of network effects in this regard? Are ICOs and CF markets complementary or substitutes?

Funding Information Open Access funding provided by Projekt DEAL.

Open Access This article is licensed under a Creative Commons Attribution 4.0 International License, which permits use, sharing, adaptation, distribution and reproduction in any medium or format, as long as you give appropriate credit to the original author(s) and the source, provide a link to the Creative Commons licence, and indicate if changes were made. The images or other third party material in this article are included in the article's Creative Commons licence, unless indicated otherwise in a credit line to the material. If material is not included in the article's Creative Commons licence and your intended use is not permitted by statutory regulation or exceeds the permitted use, you will need to obtain permission directly from the copyright holder. To view a copy of this licence, visit http://creativecommons.org/licenses/by/4.0/.

\section{References}

Ackermann, E., Bock, C., \& Bürger, R. (2020). Democratising entrepreneurial finance: the impact of crowdfunding and initial coin offerings (ICOs). In Contemporary developments in entrepreneurial finance (pp. 277-308). Cham: Springer.

Acs, Z. J., \& Audretsch, D. B. (1988). Innovation in large and small firms: an empirical analysis. American Economic Review, 78(4), 678-690.

Acs, Z. J., \& Audretsch, D. B. (1990). Innovation and small firms. Cambridge: MIT Press. 
Acs, Z. J., Audretsch, D. B., \& Feldman, M. P. (1992). Real effects of academic research: comment. American Economic Review, 82(1), 363-367.

Acs, Z. J., Audretsch, D. B., \& Feldman, M. P. (1994). R\&D spillovers and recipient firm size. Review of Economics and Statistics, 76(2), 336-340.

Adhami, S., Giudici, G., \& Martinazzi, S. (2018). Why do businesses go crypto? An empirical analysis of initial coin offerings. Journal of Economics and Business, 100, 64-75.

Ahlers, G. K., Cumming, D., Günther, C., \& Schweizer, D. (2015). Signaling in equity crowdfunding. Entrepreneurship Theory and Practice, 39(4), 955-980.

Akerlof, G. A. (1983). Loyalty filters. American Economic Review, 73(1), 54-63.

Akerlof, G. A., \& Kranton, R. E. (2005). Identity and the economics of organizations. Journal of Economic Perspectives, 19(9), 9-32.

Audretsch, D. B., \& Feldman, M. P. (1996). R\&D spillovers and the geography of innovation and production. American Economic Review, 86(3), 630-640.

Bapna, S. (2019). Complementarity of signals in early-stage equity investment decisions: evidence from a randomized field experiment. Management Science, 65(2), 933-952. https://doi. org/10.1287/mnsc.2017.2833.

Becker, G. S. (1964). Human capital: a theoretical and empirical analysis with a special reference to education. Chicago: The University of Chicago Press.

Belleflamme, P., Omrani, N., \& Peitz, M. (2015). The economics of crowdfunding platforms. Information Economics and Policy, 33, 11-28.

Block, J. H., Colombo, M. G., Cumming, D. J., \& Vismara, S. (2018). New players in entrepreneurial finance and why they are there. Small Business Economics, 50(2), 239-250.

Boreiko, D. \& Risteski, D. (2020). Serial and Large Investors in Initial Coin Offerings. Small Business Economics. https://doi. org/10.1007/s11187-020-00338-8.

Cappa, F., Pinelli, M., Maiolini, R., \& Leone, M. (2020). Pledge me your ears! The role of narratives and narrator experience in explaining crowdfunding success. Small Business Economics. https://doi.org/10.1007/s11187-020-00334-y.

Chan, C. R., \& Parhankangas, A. (2017). Crowdfunding innovative ideas: how incremental and radical innovativeness influence funding outcomes. Entrepreneurship Theory and Practice, 41(2), 237-263.

Cohen, L. (2008). Loyalty-based portfolio choice. Review of Financial Studies, 22(3), 1213-1245.

Colombo, M. G., Meoli, M., \& Vismara, S. (2019). Signaling in science-based IPOs: the combined effect of affiliation with prestigious universities, underwriters, and venture capitalists. Journal of Business Venturing, 34(1), 141-177.

Connelly, B. L., Certo, S. T., Ireland, R. D., \& Reutzel, C. R. (2011). Signaling theory: a review and assessment. Journal of Management, 37(1), 39-67.

Cressy, R. (1992). The theory of the opportunistic entrepreneur. Small Business Economics, 4(4), 267-271.

Cumming, D., \& Johan, S. (2013). Demand-driven securities regulation: evidence from crowdfunding. Venture Capital, 15(4), 361-379.

Cumming, D. J., Vanacker, T., \& Zahra, S. A. (2019a). Equity crowdfunding and governance: toward an integrative model and research agenda. Academy of Management Perspectives. https://doi.org/10.5465/amp.2017.0208.

Cumming, D. J., Meoli, M., \& Vismara, S. (2019b). Investors' choice between cash and voting rights: evidence from dualclass equity crowdfunding. Research Policy, 48(8), 103740.

Cumming, D. J., Johan, S. A., \& Zhang, Y. (2019c). The role of due diligence in crowdfunding platforms. Journal of Banking \& Finance, 108, 105661.

Cumming, D. J., Hornuf, L., Karami, M., \& Schweizer, D. (2019d). Disentangling crowdfunding from fraudfunding. Max Planck Institute for Innovation \& competition research paper, no. 16-09.

Cumming, D., Meoli, M., \& Vismara, S. (2020). Does equity crowdfunding democratize entrepreneurial finance? Small Business Economics. Forthcoming. https://doi.org/10.1007 /s11187-019-00188-z.

Cummings, M. E., Rawhouser, H., Vismara, S., \& Hamilton, E. L. (2019). An equity crowdfunding research agenda: evidence from stakeholder participation in the rulemaking process. Small Business Economics, forthcoming. https://doi. org/10.1007/s11187-018-00134-5.

Da Cruz, J. V. (2018). Beyond financing: crowdfunding as an informational mechanism. Journal of Business Venturing, 33(3), 371-393.

Demsetz, H. (1962). The effect of consumer experience on brand loyalty and the structure of market demand. Econometrica, $30(1), 22-33$.

Drover, W., Wood, M. S., \& Zacharakis, A. (2017). Attributes of angel and crowdfunded investments as determinants of VC screening decisions. Entrepreneurship Theory and Practice, 41(3), 323-347.

Ellison, G., Glaeser, E. L., \& Kerr, W. (2010). What causes industry agglomeration? Evidence from coagglomeration patterns. American Economic Review, 100(3), 1195-1213.

Epstein, L. G., \& Schneider, M. (2008). Information, quality and asset pricing. Journal of Finance, 63, 197-228.

Feldman, M. P. (1994). Knowledge complementary and innovation. Small Business Economics, 6(5), 363-372.

Fisch, C. (2019). Initial coin offerings (ICOs) to finance new ventures. Journal of Business Venturing, 34(1), 1-22.

Fisch, C. \& Momtaz, P. (2019). Venture capital and the performance of blockchain technology-based firms: evidence from initial coin offerings (ICOs). SSRN working paper.

Fisch, C., Masiak, C., Vismara, S., \& Block, J. (2019). Motives and profiles of ICO investors. Journal of Business Research.Forthcoming. https://doi.org/10.1016/j.jbusres.2019.07.036.

Gazel, M., Schwienbacher, A. (2018). Entrepreneurial Fintech Clusters. Small Business Economics. https://doi.org/10.2139 /ssrn.3309067.

Goethner, M., Luettig, S., \& Regner, T. (2020). Crowdinvesting in entrepreneurial projects: disentangling patterns of investor behavior. Small Business Economics. https://doi. org/10.1007/s11187-020-00332-0

Grossman, S., \& Hart, O. (1986). The costs and benefits of ownership: a theory of vertical and lateral integration. Journal of Political Economy, 94(4), 691-719.

Hart, O. (2009). Hold up, asset ownership, and reference points. The Quarterly Journal of Economics, 124(1), 267-300.

Hart, O., \& Moore, J. (1990). Property rights and the nature of the firm. Journal of Political Economy, 98(6), 1119-1158. 
Hart, O., \& Moore, J. (1999). Foundations of incomplete contracts. Review of Economic Studies, 66(1), 115-138.

Hornuf, L., \& Schwienbacher, A. (2017). Which securities regulation promotes equity crowdfunding? Small Business Economics, 49(3), 579-593.

Hornuf, L., Schilling, T., \& Schwienbacher, A. (2019). Initial coin offerings, information disclosure, and fraud, CESifo working paper no. 7962.

Howell, S. T., Niessner, M., \& Yermack, D. (2018). Initial coin offerings: financing growth with cryptocurrency token sales (no. w24774). National Bureau of Economic Research.

Huang, W., Meoli, M., \& Vismara, S. (2019). The geography of initial coin offerings. Small Business Economics, Article in Press. https://doi.org/10.1007/s11187-019-00135-y.

Jensen, M. C., \& Meckling, W. (1976). Theory of the firm: managerial behavior, agency costs and ownership structure. Journal of Financial Economics, 3(4), 305-360.

Kher, R., Terjesen, S. \& Liu, C. (2020). Blockchain, Bitcoin, and ICOs: a review and research agenda. Small Business Economics. https://doi.org/10.1007/s11187-019-00286-y

Kleinert, S., Volkmann, C., \& Grünhagen, M. (2020). Third-party signals in equity crowdfunding: the role of prior financing. Small Business Economics, 54, 341-365. https://doi. org/10.1007/s11187-018-00132-7

Lindholm-Dahlstrand, A., Anderson, M., \& Carlsson, B. (2019). Entrepreneurial experimentation : a key function in systems of innovation. Small Business Economics, 53(3), 591-610.

Marshall, A. (1920). Principles of economics. London: MacMillan.

Martens, M. L., Jennings, J. E., \& Jennings, P. D. (2007). Do the stories they tell get them the money they need? The role of entrepreneurial narratives in resource acquisition. Academy of Management Journal, 50(5), 1107-1132.

Masiak, C., Block, J. H., Masiak, C., Neuenkirch, M., \& Pielen, K. N. (2019). Initial coin offerings (ICOs): market cycles and relationship with bitcoin and ether. Small Business Economics, forthcoming

Meier, O., \& Sannajust, A. (this issue). The smart contract revolution: a solution for the hold-up problem? Small Business Economics.

Mödl, M. (2019). The crowd for lemons: venture investors perceptions of an equity pecking order. Proceedings of the Seventyninth Meeting of the Academy of Management, 2019.

Moedl, M. (this issue). Deal breaker terms in equity crowdfunding for prospective venture capital? Small Business Economics.

Mollick, E. (2014). The dynamics of crowdfunding: an exploratory study. Journal of Business Venturing, 29(1), 1-16.

Momtaz, P. (2020). Initial Coin Offerings, Asymmetric Information, and Loyal CEOs. Small Business Economics. https://doi.org/10.1007/s11187-020-00335-x.
Piva, E., \& Rossi-Lamastra, C. (2018). Human capital signals and entrepreneurs' success in equity crowdfunding. Small Business Economics, 51(3), 667-686.

Proelss, J., Schweizer, D., \& Zhou, T. (this issue). Economics of philanthropy-evidence from health crowdfunding. Small Business Economics. https://doi.org/10.13140 /RG.2.2.36214.04169

Rossi, A., \& Vismara, S. (2018). What do crowdfunding platforms do? A comparison between investment-based platforms in Europe. Eurasian Business Review, 8(1), 93-118.

Rossi, A., Vismara, S., \& Meoli, M. (2019). Voting rights delivery in investment-based crowdfunding: a cross-platform analysis. Journal of Industrial and Business Economics, 46(2), 251-281.

Saxenian, A. L. (1996). Regional advantage: culture and competition in Silicon Valley and Route 128. Cambridge: Harvard University Press.

Schückes, M., \& Gutmann, T. (this issue). Why do startups pursue initial coin offerings (ICO)? The role of economic drivers and social identity on funding choice. Small Business Economics. https://doi.org/10.1007/s11187-020-00337-9.

Spence, M. (1973). Job market signaling. Quarterly Journal of Economics, 87, 355-374.

Sussan, F., \& Acs, Z. (2017). The digital entrepreneurial ecosystem. Small Business Economics, 49, 55-73.

Vanacker, T., \& Forbes, D. P. (2016). Disentangling the multiple effects of affiliate reputation on resource attraction in new firms. Organization Science, 27(6), 1525-1547.

Vanacker, T., Forbes, D. P., Knockaert, M., \& Manigart, S. (2019). Signal strength, media attention, and resource mobilization: evidence from new private equity firms. Academy of Management Journal. https://doi.org/10.5465 /amj.2018.0356.

Vismara, S. (2016). Equity retention and social network theory in equity crowdfunding. Small Business Economics, 46, 579590.

Vismara, S. (2018). Information cascades among investors in equity crowdfunding. Entrepreneurship Theory and Practice, 42(3), 467-497.

Vismara, S. (2019). Sustainability in equity crowdfunding. Technological Forecasting and Social Change, 141, 98-106.

Williamson, O. E. (1985). The economic institutions of capitalism. New York: The Free Press.

Publisher's note Springer Nature remains neutral with regard to jurisdictional claims in published maps and institutional affiliations. 